\title{
Exploring the New Situation of Ideological and Political Work for College Students with the Spirit of "Seeking Truth from Facts"
}

\author{
Changping $\mathrm{Ke}^{1, \mathrm{a}}$ \\ ${ }^{1}$ Qujing Normal University, Qujing, Yunnan, 655011
}

Keywords: University Ideological and Political Work, Seeking Truth Spirit, New Situation

\begin{abstract}
As a teacher engaged in the teaching of ideological and political education, he has formed a clear idea in his long-term thinking and theoretical teaching, that is, the macro politics that he seems to teach from the ones that seem to be only the future and the fate of the country Theory, guide themselves and students to understand the implication of the scientific way of thinking, and in the daily work, study and life in the body, and strive to creatively put things well. Along this line of thought, whether they are standing on the pulpit on the ideological and political education theory of teaching, or as the class teacher for students of ideological and political work, are trying to use their own experience and summed up the way of thinking to work, and each time there are some New harvest. In order to facilitate the discussion, I put these years on their own teaching and class teacher in the work of ideological and political education to carry out the more prominent "realistic" thinking of the understanding and implementation of a simple summary of the purpose of working with colleagues to discuss how to do a good job Ideological and Political Work of College Students in the New.
\end{abstract}

\section{Introduction}

As we all know, "seeking truth from facts" as our party's ideological line, Mao Zedong for the first time put forward. He is in the "transformation of our study," a paper that: "practical" is the objective existence of all things, "is" is the objective things of the internal relations, that is, regularity, "seeking" is that we study. [1] In short, is from reality, to explore things regularity, according to objective laws. Looking back at the course of our party's leadership of the Chinese revolution and socialist construction, we can easily find out that when we insist on "seeking truth from facts", our cause is flourishing and vice versa. It can be seen that the reason why "seeking truth from facts" has become the ideological line of our party is fundamentally because it is a scientific way of thinking, it is more in order to solve the problem more effectively if it is used to analyze the problem and deal with the problem more in line with the objective laws The Therefore, we should carry out the ideological and political education of college students should learn from this way of thinking, starting from the reality of college students, starting from the mission of college teachers, starting from the characteristics of the work of the university class teacher, do a good job of ideological and political education of college students The

\section{Shape the Health of College Students Psychological with the Spirit of "Seeking Truth From Facts"}

The psychological problems of college students are very concerned about the current colleges and universities. From the actual situation of our school in recent years, the great employment pressure, interpersonal tension and poverty face is a few important aspects of mental health problems caused by college students. I am also concerned about the ideological and political work of students are also concerned about these issues, and in the spirit of seeking truth from facts to guide them to correctly view these issues. Specifically, when I talk about the theory of socialist market economy, it is often combined with the current huge employment pressure to carry out some analysis, so that students solve the past college students "package distribution" of the planned economic complex, understand the market as a human resource allocation For each of us to provide a broader space for development, each person will have more opportunities, but the premise is that we must be a real 
resource, but also to become a rare resource. I specifically put the campus online browsing the most called "Who abandoned college students?" I tell you! "The post read to the students to listen to, it is clear that this logical clear, language sharp article so that many students have been shocked in the" employing units and college students have hatred? If you use, why they do not have reason? , Since he needs to be employed, then you do not have to show that you are not the person he needs. Is it good to listen to the logic class in school? "[2] In the expression, they began to understand that only hard work and effort It is possible to smooth employment, they no longer complain about untimely, accusing the community on their own injustice, they know the fate in their own hands, and thus more hard work, more efforts to up, more full of youthful vigor. Similarly, in teaching our party "seeking truth from facts" ideological line, I also consciously combined with college students interpersonal problems in the main problems, especially from the analysis of our side of our school a girl suicide direct cause - students To help them establish a divided into two people in the world, in the class together to learn to appreciate and enlarge the advantages of others, tolerance and reduce the shortcomings of others, do not easily take their own advantages to others than others Of the shortcomings, to see who is not pleasing to the eye, thus deteriorating interpersonal relationships, as well as the loss of confidence in life.

In view of the mental health problems that may arise from the poor face of our school students, I often start from the perspective of seeking truth from facts in the class teacher's work. First, I will understand the family situation of the poor students and try to prove them through various channels. , On this basis, the poor situation of students to do a serious and general, short and long-term classification, and thus as a future basis for helping poor students; followed by convening poor students meet, from the ideological guide them to establish "Seeking truth from facts" point of view, face up to the status quo of their own family poverty, do not avoid poverty, should be calm attitude to face themselves and others. To understand that poverty is not a fault, it is not a shameful thing, in the case of possible to actively seek the help of others to ease the pressure of their lives, but to help their people to be grateful and provide them with the ability to help. Encourage poor students to self-reliance, establish a positive attitude towards life, become a useful for the community and others. Once again, with the consent of the poor students, ask them to class in the class in front of the class to make their own family economic situation to do an introduction, on the one hand makes the next four years in the allocation of school poverty subsidies more fair and just, On the other hand also let other students a comprehensive understanding of the situation of poor students, and under the guidance of teachers to correctly view the special situation faced by poor students, to avoid the poor students due to family circumstances caused by unintentional harm, and then in the class Establish a non-poor students friendly to help poor students, poor students through their own efforts to actively take the initiative for the class and others to make their own contribution to the harmonious atmosphere. In addition, through the poor students to introduce some work-study opportunities to help them alleviate the economic and spiritual pressure to let them see through their own struggle to change poverty is feasible, thereby enhancing the confidence of life, and establish a healthy and positive attitude towards life The

\section{Cultivate the Integrity of College Students Character with the Spirit of "Seeking Truth From Facts"}

Honesty is the conduct of college students, but also its basic premise for the benefit of society. Cultivating the integrity of college students, not only can benefit from life, but also help to promote the establishment of the entire social integrity system. From the reality, the lack of honesty and credit education of college students to strengthen the integrity of education has become a top priority. Combined with teaching and class teacher work, I often against the lack of integrity of our school students the most prominent two manifestations - arrears of tuition fees and cheating, in addition to the macro theory from the "integrity of the role of a person, integrity in life important Sex "and in each semester, around the integrity of the development of a number of thematic activities, so that integrity" India "in each student's mind outside.

On the issue of arrears of tuition, I first analyzed the changes in the fees and charges of higher 
education, starting from the low cost of paying the university in the last 80s, and objectively expounded the fees caused by the development of the market economy and the higher education reform Changes in the rules, emphasizing the new conditions can only comply with the new rules, the planned economy under the high education almost no tuition remembrance and miss is conservative, but also meaningless. I led the students to seek truth from facts to analyze the main reasons for the tuition fees of our students: or family poverty; In the case of family poverty, the school can provide student loans for students to apply for bank loans according to the relevant policies of the state, and student loans can help students to pay tuition fees in full. Therefore, there is no reason for poor students in ordinary poor families to I have no money to pay tuition fees for reasons. If you obviously can borrow money you do not want to borrow the tuition fees, needless to say, it is sure you have a problem. In the case of deliberate arrears, even more should not, you can say that others are owe, why do you want to pay? That is to learn from others. Tuition is the obligation and responsibility of college students, the reason is like buying things to pay the other as simple as each other. There is only two reasons for not paying: one - Sure to be someone else's supercilious, but also by the corresponding punishment; the second - worthless! If you do not think that you can return, put things back to others, you can not things to be, money is not paid, this argument certainly does not meet the rules of the market economy. After establishing this concept, our class never had students owed tuition fees, even the poorest students - an orphan, and never owed tuition, in his words: the state, the school and the class The borrower borrowed, the given to the, I have any reason to say that there is no money to pay tuition fees?

On the question of cheating on the exam, I led the students to analyze the causes of college students' cheating in a practical way. First of all, there were some problems in the curriculum. For example, the English test has always been a hurdle in front of college students, so now the students are focused on learning English, ignoring the other courses, especially elective courses. Examination of these courses will naturally have to ponder some "ideas". Second, the examination is not scientific enough. Many courses have always attached importance to the assessment of memory knowledge. An explanation of a particular problem, the teacher used to list the "one, two, three, four ... ..." a number of points, and then put these as the standard answer to the exam. Some students think that such a dead knowledge does not make much sense, but also the lack of sufficient interest, in order to cope with clearance, willing to take risks. Finally, utilitarian education philosophy and value standards are the dominant factors in the phenomenon of cheating. Although the academic performance is not as important as that of junior high school and high school, it is still one of the indicators to measure the quality of college students, and sometimes even the only measure that measures the quality of college students. Good results can get high scholarships, can be directly recommended for exemption for graduate students $\ldots$... the concept of examination-oriented education is still prevalent in the university, the assessment of student skills is also a little single, which have led to the emergence of poor competition, some students Will be unscrupulous to improve their scores. Based on the above analysis, I emphasize two points to the students: first, to adapt to the current examination environment, because the examination requirements for everyone are the same, so it is at least fair. And even such an exam, who dares to say it is useless? "Adaptation" What you do not like is a kind of ability, "rote" as an important way to learn knowledge and accumulate knowledge, it is a kind of ability. Second, in the teaching interaction and teaching in a better way to promote the reform of teaching management system and the concept of renewal of the examination, and should not be used to cheat such a negative way to meet these drawbacks. This analysis and discussion is not only a simple emphasis on maintaining integrity, more profound analysis in the face of some difficulties and dissatisfaction still follow the principle of good faith, at any time can not be any excuse against the principle of good faith, this is our The character of college students.

\section{Cultivate the Sense of Responsibility of College Students with the Spirit of "Seeking Truth From Facts"}

21st century college students not only require a certain knowledge and ability, but also have a 
strong moral quality, responsibility is one of the core qualities. And contemporary part of the sense of responsibility of college students appear to play down the phenomenon is worrying. At present, the lack of responsibility to make part of the students skip the Internet, overnight Internet, because of obsession with the network and abandoned school, or even dropped out, completely forgotten as a college student's social responsibility and historical mission. University stage is an important stage of life, is the accumulation of talent, college students should be better for their own life orientation, a clear goal of life and to achieve the goal of unremitting efforts to become the pillars of the motherland needs. Therefore, teachers should carry out ideological and political education, strengthen the sense of responsibility for college students education.

In the principle of seeking truth from facts, the sense of responsibility of college students should start with the consciousness of being responsible for themselves. The reasons are as follows: First, the consciousness of being responsible for oneself is more likely to be accepted emotionally for college students because they feel more and more Second, the sense of self-responsibility is to cultivate the basis and starting point of social responsibility of college students, only responsible for the community and not responsible for their own responsibility is too idealistic and inhumane. Based on the above understanding, I often combined with learning and life problems to guide students to establish their own point of view. So that students understand the responsibility is not only the obligation and pay, in fact, many times is a right and get. For example, some students because of various reasons to skip classes, but also often the teacher did not name and punishment and feel fortunate, not knowing that skip class absentee behavior in the expression of their lack of responsibility at the same time, in fact, gave up their right to access to knowledge, Seemingly take advantage of the back but ate the loss and completely feel. Another example, college students to buy insurance, I am in line with the desire to cultivate college students for their own, there is no mandatory requirements for students to buy insurance, but by talking about their own understanding of the insurance method, in the school of typical students get insurance compensation Situation and case, the use of "usually inject a drop of water, difficult to have the Pacific" advertising emphasis stressed: insurance is their own rather than others, if the savings for the purpose of tens of dollars, you give up the purchase of insurance, then please You must remember that once the accident occurred in your body need money, and you have the ability to come up with so much money, then in the face of schools, teachers and students do not want to actively help you, please do not sigh "The warmth of human beings" and "the inconstancy of the world", because the culprit leading to all this is actually what you have been responsible for their own, a person who is not willing to be responsible for their own rights and qualifications of others Are you responsible? Although this guidance did not reach $100 \%$ of the insurance rate (only 92\%), but I still have a heart than in the past to achieve $100 \%$ of the insured rate more pleasant feeling, I really experience a University class teacher from the "nanny" to "mentor" change the success.

Summed up the years of experience and lessons, I found that in the ideological and political education of college students can not disregard the actual use of some large and empty reason to educate students. Only in the spirit of seeking truth from facts, everything from the reality of the spirit, can get rid of the traditional way of thinking, with a more active and active attitude to explore ways to improve the ideological and political work of college students, and create a new situation of ideological and political work of college students.

\section{References}

[1] Mao Zedong. Mao Zedong's Selected Works (Volume III) [M]. Beijing: People's Publishing House, 1991.801.

[2] Who abandoned college students? I tell you! Http://www.cc222.com/article/278117.html 